УДК 94(4); 902

DOI: $10.18384 / 2310-676 X-2021-5-9-15$

\title{
CENTRAL EUROPEAN CRISIS, CULTURE HETEROGENIZATION AND MIGRATIONS FROM THE STEPPES IN NEOLITHIC
}

\section{S. Kadrow}

Institute of Archaeology, Rzesz w Univeristy

Moniuszki 10; 35-015 Rzesz w, Republic of Poland

\begin{abstract}
Aim. To show the symptoms of the socio-economic crisis in Central Europe $\left(2^{\text {nd }}\right.$ part of the 4 th milIennium BC) and the accompanying cultural mechanisms.

Methodology. The author uses the tools of the globalization theory (network connectivity etc.) and the theory of culture (hetreogenization, hybridization etc.) to analyze the effects of a long-term crisis. Results. Attention was drawn to the probable correlation of the crisis and the accompanying cultural changes with the increasing migrations from the steppes and their positive impact on deep cultural changes, i. e. the formation of the Corded Ware Culture.

Research implications. The described situation finds structural analogies in late antiquity (the fall of Rome in the conditions of the growing strength of early Christian network communities) and today according to Oswald Spengler's idea of the fall of the West (Untergand des Abendlandes).

Keywords: Central Europe, steppe migrations, crisis, hybridization, heterogenization, culture change

\section{ЦЕНТРАЛЬНОЕВРОПЕЙСКИЙ КРИЗИС, НЕОДНОРОДНОСТЬ КУЛЬТУРЫ И МИГРАЦИИ ИЗ СТЕПЕЙ В НЕОЛИТЕ}

\section{Кадров C. $\boldsymbol{P}$.}

Институт археологии, Жешувский университет

Монюшки 10; 35-015 Жешув, Республика Польша

\section{Аннотация}

Цель. Показать симптомы социально-экономического кризиса в Центральной Европе (вторая часть 4 тыс. до н. э.) и сопутствующие ему культурные механизмы.

Процедура и методы. В исследовании использованы инструменты теории глобализации (сетевая связность и т. д.) и теории культуры (гетерогенизация, гибридизация и т. д.) для анализа последствий долгосрочного кризиса.

Результаты. Обращено внимание на вероятную взаимосвязь кризиса и сопутствующих культурных изменений с увеличением миграций из степей и их положительным влиянием на глубокие культурные изменения, т. е. формирование культуры шнуровой керамики.

Теоретическая и/или практическая значимость. Описанная ситуация находит структурные аналогии в поздней античности (падение Рима в условиях растущей силы раннехристианских сетевых сообществ) и сегодня в соответствии с идеей Освальда Шпенглера о падении Запада (Untergand des Abendlandes).

Ключевые слова: Центральная Европа, степные миграции, кризис, гибридизация, гетерогенность, изменение культуры

() СС ВY Кадров С. Р., 2021 


\section{Introduction}

The aim of the article is to describe the crises affecting Neolithic communities in the $2^{\text {nd }}$ half of the $4^{\text {th }}$ millennium BC in Central Europe. Due to the advancement of the state of research, such phenomena have been described on the example of south-eastern Poland and central Germany. In the abovementioned areas and additionally in Kuyavia, intensive processes of heterogenization and hybridization of cultures were found. At the end of the $4^{\text {th }}$ millennium BC, traces of the presence of graves typical of the Yamnaya (Hubinek) culture, and even earlier, "preyamnaya» influences (Malczyce) come from south-eastern Poland. So there was a temptation to make a hypothesis whether the crisis situations and the accompanying socio-cultural changes in the form of the dominance of horizontal network structures and intense hybridization do not create favorable conditions for the absorption of steppe migrants and profound cultural change?

\section{The Fall of Neolithic Societies}

Janusz Kruk and Sarunas Milisauskas, analyzing the material evidence of everyday activities of the Neolithic communities in south-eastern Poland, identified multiple symptoms of the crisis in the socio-economic sphere from the middle of the 4th thousand BC [14, p. 171-208].

The aforementioned crisis, or «Fall of Neolithic Societies», was preceded by a «Rize» of them (as it was expressed in the title of the book: "The Rize and Fall of Neolithic Societies» [14]), which began with the arrival of the oldest Danubian farmers in south-eastern Poland, and reached its peak with the development of Funnel Beaker culture.

The most spectacular symptoms of the crisis in south-eastern Poland are visible in the transformations of the settlement network. It is about a drastic decrease in the number of large settlements in the Bronocice region, that took place with the formation of syncretic (Funnel Beaker-Baden) cultural complexes of the Bronocice IV-V type [14, p. 171-176]. During the BR V phase $54 \%$ of the entire population of the whole region was concentrated at the site of Bronocice. For this reason, this process was called «the stage of reduction and concentration of settlement» [14, p. 174-176]. The population of the region also decreased (from 6200 in BR II to 900 in BR V).

Ecological factors seem inadequate to explain these changes $[14$, p. 330]. Their most likely cause was an internal conflict [7, p. 239-240], which probably also took on bloody forms. This is indirectly indicated by the burial data from Bronocice site which seems to point to an anomalous catasatrophic event, an epidemic or a masacre $[18$, p. $55-$ 86]. In turn, the increase in the number of flint axes and the fortifications of the settlement in the Bronocice $\mathrm{V}$ phase increase the probability of military events [14, p. 330].

Similar crisis trends can be noticed in other areas of Central Europe, such as in East Westfalen and Hessen, in the North-Alpine area, in Bohemia and Moravia and southern Scandinavia and first of all in Central Germany [19, p. 427-437].

The overexploitation of the environment and other archaeologically hard-to-grasp causes led to crisis situations that resulted in serious social changes, taking place in different ways in different regions. The processes of change were not completely synchronous. In Denmark and south-eastern Poland, their intensification took place around $3300 \mathrm{BC}$, while, for example, in East Westfalen and Hessen around 2800 BC [19, p. 437]. The causes of the crisis could have been different for each region. Sometimes they were transcultural networks for the exchange of goods and ideas, other times migration movements or climate change etc. [19, p. 438].

Extensive study of the Central German (Mittelelbe-Saale-Gebiet) Neolithic has led to similar but more specific conclusions [19, p. 268-426]. «Since $3500 \mathrm{BC}$ cal some form of crisis is obvious, which might be result of new difficulties in accessing eastern alpine copper raw material. Furthermore, the changes in the Altmark with the appearance 
of Tiefstich might be the reason for some kind of instability in the central Elbe and Saale region. As a result, the diversity of ceramic decoration, which seems to reflect the need for the expression of group boundaries, grows» [19, p. 424, 445, fig. 261].

Foundation of satellite settlements (during secondary colonisation - «Landesausbau») reduced the significance of central sites (and central institutions). In consequence smaller enclosures formed structural fixed points on a local level [19, p. 424, 445].

\section{Culture heterogenization and hybridization}

The phenomenon of cultural heterogenization was observed as early as the end of the $19^{\text {th }}$ century. Units of this type were called syncretic cultures. Mixed cultures were considered by traditional archaeologists to be an example of deviation from the norm, that is, something special, an exception ${ }^{1}$.

Cultural studies today question the definition of culture as a homogeneous entity with clearly delimited ranges [1, p. 47, 294]. Hybridization - combination of at least two different cultures [3] - takes place mainly in the periods of operation of globalization processes. Hybrids destabilize and blur cultural boundaries. Hybridity is contrary to the mechanisms of the center-periphery or world system relationship. The idea of hybridization helps to notice the processes of creating new identities and cultural forms [1, p. 293-295, 317].

In times of intensification of crisis phenomena in the most important settlement regions of Central Europe, vivid processes of culture, heterogenization and hybridization, are observed.

One of the examples of such a cultural hybrid in south-eastern Poland is the Wyciąże group of mixed Polgar-Baden character [8; $9 ; 20]$. In the light of radiocarbon chronology the Wyciąże group is placed within the younger stage of the Proto-Baden horizon,

\footnotetext{
Kadrow S., Krzywda A., Naglik R. Wyciąże group and other heterogenic culture entities in $4^{\text {th }}$ millennium of Central Europe. 2022. (in press).
}

which means within 3500-3100 BC [25, p. 145].

Another cultural hybrid is the unit called Funnel Beaker - Baden, distinguished years ago on the basis of late materials from the site in Bronocice, BR IV - BR V phases [12; 13]. Another cultural hybrid is the unit called Funnel Beaker - Baden, distinguished years ago on the basis of late materials from the site in Bronocice [15, p. 123-127]. This hybrid is dated from 3300-2800 BC [16, fig. 20].

The above-mentioned hybrids developed in close proximity to a large crowd of so-called "normal" cultures. In the light of Marek Nowak's latest studies [21] in the 4th millennium BC, the only unit present in western part of south-east Poland all this time was the Funnel Beaker Culture (3750-3100 with a maximum development between 3500 and $3300 \mathrm{BC}$ ). The settlement of the LublinVolhynia Culture (3900-3600 BC) occurs in the loess uplands between the Dłubnia in the west and the Nida in the east, and in the loess foothills near the Raba valley [21, fig. 2]. The late-Polg6r group of Wyciąże-Złotniki (3900-3600 BC) is limited in its occurrence to the vicinity of Krakyw-Nowa Huta and the foothills located directly south of the Vistula [21, fig. 2]. The population of the Funnel Beaker-Baden (3300-3100 BC) was limited to the settlement of the loess highlands between the Szreniawa and Nida rivers. To the west of the mentioned unit, i. e. to the west of Szreniawa and Raba, there were communities of the Baden culture (3100-2800 BC).

Communities of the hybrid group called Wyciąże, inhabited a small area where the population of Lublin-Volhynia Culture previously and to some extent at the same time lived, together with the late Polgár (WyciążeZłotniki) and Funnel Beaker Culture. Probably at the end of the existence of the Wyciąże group, it was contemporary to the Baden culture $^{2}$.

In Kuyavia throughout the $4^{\text {th }}$ millennium BC, Funnel Beaker Culture settlement

\footnotetext{
2 Kadrow S., Krzywda A., Naglik R. Wyciąże group and other heterogenic culture entities in $4^{\text {th }}$ millennium of Central Europe. 2022. (in press).
} 
was dominant. It was accompanied by traces of the presence of an epimezolytic population [4, fig. 3]. Final phase of Brześć Kujawski Culture survived probably in this region at the beginning of this millennium. Then its place was taken by the Globular Amphorae culture [4, fig. 3, 29].

The first heterogeneous cultural units in Kuyavia were the Matwy and Radziejyw Kujawski groups in the mid of $4^{\text {th }}$ millennium BC. Peculiar face of the Mątwy group was determined by the presence of elements of the Trypillia culture [10]. The second one is a local variation of the Funnel Beaker and Baden culture [22].

Particular intensification of the processes of heterogenization and cultural hybridization took place in the $4^{\text {th }}$ millennium BC at Central Germany (Mittel-Elbe-Saale Gebiet). Side by side, numerous cultural units with different levels of advancement of syncretization processes and of different origins existed [19, p. 63-248, fig. 140-141] in a relatively small area $[19$, p. $57-58$, fig. 5). As time passed, the hybridization process intensified.

As in the case of south-east Poland, the Funnel Beaker Culture was present throughout the millennium. Initially, apart from the aforementioned Funnel Beaker Culture, the tone was set by Michelsberg and Baalberge, with the participation of the Jordansmühl culture. Starting from the middle of the 4th millennium Baden Culture, Globular Amphorae Culture, Salzmünde and Bernburg and a whole series of syncretic local groups began to prevail [19, fig. 140-141].

Other examples, however not so intense processes of hybridization of cultures are also readable in other regions of central Europe [19, p. 427-438].

\section{Horizons of the influence (infiltrations) of the steppe population in the areas of central Europe}

In recent years, researchers distinguish stages of the influence of the steppe population in the areas of Central Europe to the north of the Carpathians $[11 ; 24]$.
The oldest stage is represented by burials from a barrow in Hubinek in the western part of the Volhynia Upland (ca. 3000 BC). Three graves with Yamnaya culture features were discovered there.

The second stage is related to the barrows of the oldest horizon of Corded Ware culture (ca. 2900-2700 BC).

In the third period, burials in catacombs appear, showing similarities to the features of Dnieper culture features.

The fourth migration trend is represented by Bell Beaker culture burials (ca. 2400$2250 \mathrm{BC}$ ), however, the eastern steppe nature of this culture is problematic.

The fifth wave is represented by burial mounds from the beginning of Strzyżów culture (around 2000 BC). A barrow in Stryjów in the Lublin Upland is typical of them.

The above-mentioned stages of steppe influences were represented primarily by the infiltration of increasingly larger, with the passage of time, groups of the steppe population in Central Europe. Much earlier, around $3500 \mathrm{BC}$, circular mounds appeared in south-eastern Poland in the context of the Funnel Beaker Culture (for example in Malczyce), testifying to the influences of the steppe groups of an undefined nature [24, p. 3, fig. 15].

Due to such an early chronology, Eastern impulses had to come from the pre-yamnaya backgrounds represented by the NizhneMikhailovka and Kvityana cultures [5, p. 47].

The main impetus of influences and migrations from the steppes was towards the lower Danube and then further south to Bulgaria and up the Danube to the eastern part of the Tisza river basin [5, p. 47]. The western direction, north of the Carpathians, was not subjected to such intense influence.

\section{Conclusion}

The Yamnaya culture, played an important role in shaping the gene pool of Corded Ware Culture and Bronze Age Europeans, which extends into present-day patterns of genetic variation in Europe [6]. The results of genetic tests confirm the significant share of 
migration within the so-called steppe influences in the area of central Europe.

In the case of the lower Danube, intensive migrations from the east are already readable from $3300 \mathrm{BC}$. Their origins were related to the cultural units known as "preyamnaya", since the Yamnaya culture is dated only from 3050/3000 BC [5, p. 46].

To the north-east of the Carpathians, the beginnings of systematic migration from the steppes date back to around $3000 \mathrm{BC}$. Cultural communities of Zhivotilovka-Volchansk, Gordinești and early Yamnaya participated in them [24, p. 3].

In times of domination of horizontal network structures the phenomena of polyculturalism, heterogenization, multi-ethnicity $[17$, p. $8,28,161,212]$ and heterarchy appear. At the same time hierarchical ties typical of the world system [23], or the relationship between the center and the periphery [2] are relegated to the background. Late antiquity (the spread of early Christianity; see «The History of the Decline and Fall of the Roman Empire» by Edward Gibbon ) and modern times («Untergang des Abendlandes» by Oswald Spengler or «Le temps des tribus» by Michel Maffesoli) are an excellent illustration of the flourishing of hybrid cultures [17, p. 164] in the conditions of a deepening socio-cultural crisis.

It goes without saying that the crisis of the late antique world facilitated the barbarians' invasions on the Roman state, or even encouraged them to do so and led to a complete restructuring of the world at that time.

Due to the coexistence of many of the same structural phenomena in both horizons (late antiquity and the second half of the $4^{\text {th }}$ millennium BC in Central Europe), such as crisis, network connectivity, polyculturalism, heterogenization, hybridization, multi-ethnicity, migrations, heterarchy etc., the world of declining Rome can serve as an interpretive model for socio-cultural and economic phenomena and processes that took place 3500 years earlier.

Дата поступления в редакиию 28.09.2021

\section{REFERENCES}

1. Barker C. Studia kulturowe. Teoria i praktyka. Kraków, Wydawnictwo Uniwersytetu Jagiellońskiego. 2005. 659 p.

2. Braudel F. Civilisation matérielle, économie et capitalisme, XV-XVIII siècle. Vol 1. Les Jeux del'Echange. Paris, Armand Colin, 1979. 551 p.

3. Canclini N. G. Hybrid Cultures. Strategies for Entering and Leaving Modernity. Minnesota, University of Minnesota Press, 1990. 280 p.

4. Cofta-Broniewska A., Kośko A. Historia pierwotna społeczeństw Kujaw. Warszawa-Poznań, PWN, 1982. 285 p.

5. Frînculeasa A., Preda B., Heyd V. Pit-Graves, Yamnaya and Kurgans along the Lower Danube: Disentangling IVth and IIIrd Millennium BC Burial Customs, Equipment and Chronology. In: Praehistorische Zeitschrift, 2015, vol. 90 (1-2), pp. 45-113.

6. Juras A., Chyleński M., Ehler E., Malmström H., Żurkiewicz D., Włodarczak P., Wilk S., et al. Mitochondrial genomes reveal an east to west cline of steppe ancestry in Corded Ware populations. In: Scientific Reports, 2018, no. 8 (1). DOI: 10.1038/s41598-018-29914-5.

7. Kadrow S. Concept of the 'stage of reduction and concentration of settlements' in the Neolithic studies. Demography, settlements and social conflict. In: Documenta Praehistorica, 2020, vol. 47, pp. 232-244.

8. Kadrow S., Krzywda A., Naglik R. Szarbia, site 7, Comm. Koniusza. Graves and settlements from the Neolithic to the Early Bronze Age. In: Naglik R., ed. Szarbia, site 7, Comm. Koniusza. Settlements and Cemeteries from Neolithic to the Roman Period (Biblioteka Muzeum Archeologicznego w Krakowie 9). Kraków, Muzeum Archeologiczne, 2019, pp. 23-119.

9. Kadrow S., Krzywda A., Naglik R. Relics of the Eneolithic Wyciąże Group at Site 7 in Szarbia, Lesser Poland. In: Slovensk6 archeolygia, 2020, vol. 68, pp. 307-316.

10. Kośko A. Udział południowo-wschodnioeuropejskich wzorców kulturowych w rozwoju niżowych społeczeństw kultury pucharów lejkowatych. Grupa mątewska. Poznań, Uniwersytet im. Adama Mickiewicza, 1981. 222 p. 
11. Kośko A., Włodarczak P. A Final Eneolithic Research Inspirations: Subcarpathia Borderlands between Eastern and Western Europe. In: Baltic-Pontic Studies, 2018, vol. 23, pp. 259-291.

12. Kruk J., Milisauskas S. Wyżynne osiedle neolityczne w Bronocicach, woj. Kieleckie. In: Archeologia Polski, 1981, vol. 26, pp. 65-113.

13. Kruk J. Milisauskas S. Chronologia absolutna osadnictwa neolitycznego z Bronocic, woj. Kieleckie. In: Archeologia Polski, 1983, vol. 28, pp. 257-320.

14. Kruk J., Milisauskas S. Rozkwit i upadek społeczeństw rolniczych neolitu. Kraków, Instytut Archeologii i Etnologii Polskiej Akademii Nauk, 1999. 403 p.

15. Kruk J., Milisauskas S. Bronocice. The Chronology and Development of a Neolithic Settlement of the Fourth Millennium BC. Kraków, Institute of Archaeology and Ethnology. Polish Academy of Sciences, 2018. 304 p.

16. Kruk J., Milisauskas S. Real Time. Radiocarbon Dates and Bayesian Analysis of the Neolithic Settlement at Bronocice, Fourth Millennium BC. Kraków, Institute of Archaeology and Ethnology, Polish Academy of Sciences, 2018. 153 p.

17. Maffesoli M. Czas plemion. Schyłek indywidualizmu w społeczeństwach ponowoczesnych. Warszawa, PWN, 2008. 253 p.

18. Milisauskas S., Kruk J., Pipes M.-L., Haduch E. Neolithic human burial practices. The interpretation of funerary behaviors at Bronocice, Poland. Kraków, Institute of Archaeology and Ethnology, Polish Academy of Sciences, 2016. 318 p.

19. Müller J. Soziochronologische Studien zum Jung- und Spätneolithikum im Mittelelbe-Saale-Gebiet (4100-2700 v. Chr.). Eine sozialhistorische Interpretation prähistorischer Quellen (Vorgeschichtliche Forschungen 21). Rahden/Westf., Verlag Marie Leidorf GmbH, 2001. 620 p.

20. Naglik R., ed. Szarbia, site 7, Comm. Koniusza. Settlements and Cemeteries from Neolithic to the Roman Period. Kraków, Muzeum Archeologiczne, 2019. 411 p.

21. Nowak M. The Funnel Beaker Culture in Western Lesser Poland: Yesterday and Today. In: Archaeologia Polona, 2019, vol. 57, pp. 79-101.

22. Przybył A. From south to north. Baden culture people and their neighbours. In: Urbańczyk P., ed. The Past Societies. Polish Lands from the First Evidence of Human Presence to the Early Middle Ages. Warszawa, Instytut Archeologii i Etnologii PAN, 2017, pp. 171-209.

23. Wallerstein I. The Modern World System. New York, Academic Press, 1974. 440 p.

24. Włodarczak P. Eastern impulses in cultural and demographic change during the end of the southeastern Polish Eneolithic. In: Heyd V., Kulcsár G., Preda-Bălănică B., eds. Yamnaya Interactions : proceedings of the International Workshop, Helsinki, 25-26 April 2019 (Yamnaya Impact on Prehistoric Europe 2). Budapest, Archaeolingua, 2021, pp. 1-27.

25. Zastawny A. Absolute chronology of the Baden Culture in Lesser Poland - New Radiocarbon Dates. In: Nowak M., Zastawny A., eds. The Baden culture around the Western Carpathians (Via Archaeologica. Źrodła z badań wykopaliskowych na trasie autostrady A4 w Małopolsce). Kraków, Krakowski Zespół do Badań Autostrad, 2015, pp. 191-219.

\section{INFORMATION ABOUT THE AUTHOR}

Sławomir R. Kadrow - Dr. Sci. (Archeology), Prof., Institute of Archaeology, Rzeszów Univeristy; e-mail: slawek.kadrow@archeologia.rzeszow.pl

\section{ИНФОРМАЦИЯ ОБ АВТОРЕ}

Кадров Славомир Ромуальд - доктор археологии, профессор Института археологии Жешувского университета;

e-mail: slawek.kadrow@archeologia.rzeszow.pl

\section{FOR CITATION}

Kadrow S. Central European crisis, culture heterogenization and migrations from the steppes in Neolithic. In: Bulletin of Moscow Region State University. Series: History and Political Sciences, 2021, no. 5, Circumpontica, iss. III, pp. 9-15.

DOI: $10.18384 / 2310-676 \mathrm{X}-2021-5-9-15$ 


\section{ПРАВИЛЬНАЯ ССЫЛКА НА СТАТЬЮ}

Кадров С. Центральноевропейский кризис, неоднородность культуры и миграции из степей в неолите // Вестник Московского государственного областного университета. Серия: История и политические науки. 2021. № 5. Циркумпонтика. Вып. III. С. 9-15.

DOI: $10.18384 / 2310-676 X-2021-5-9-15$ 